\title{
The Island in Conceição Lima’s Poetry
}

JOANA CASTAÑO

Universidad de Oviedo

\begin{abstract}
In this article, I focus on the poetry of Conceição Lima, born in Santana, São Tomé, in 1961. I analyze the relationship between the poetic voice and the island, as well as the imagery conceived in Lima's work, which explores the consequences of nationhood. Of special interest is Lima's treatment of the island as both an abtract form and an empirical reality. Through readings of a broad cross-section of Lima's work, I argue that for her the island ultimately comes to represent home.
\end{abstract}

Keywords: São Tomé e Príncipe; Island poetry; House; Homeland; Nation

"Life begins well, it begins enclosed, protected, all warm in the bosom of the house."

(Bachelard 84)

The theme of the island runs across the history of literature, from Plato up to the present day. It is a symbol of a vital spiritual setting, an earthly paradise and haven or even a utopia, where the subject may be detached from reality and live in safety, isolation, and intimacy, secure from the world outside (Tomé 18). In San Tomean literature, the island plays a crucial role. Francisco José Tenreiro's Ilha de Nome Santo (1942), a foundational work of San Tomean literature, opens a new relation between the poetic voice and the island, as Inocência Mata points out (Polifonias 55). For Tenreiro, the island is no longer portrayed as a luxurious geographical area, but rather as a symbol of "África violentada, inchada de cólera, a esperança feita revolta" (Ferreira 84). 
A common symbol, the island assumes a unique dimension in Conceição Lima's work, sometimes empirically mentioned, sometimes an "island of the imagination" (Macedo 9) coinciding with a foundation and intimate place, for which terms such as "mátria," “casa," "útero da casa," "país," "praça," "raiz” and "raiz do micondó" are invoked. They indicate a "busca identitária do sujeito poético que reclama um local de origem, que é também o lugar de enunciação a partir do qual o sujeito poético coloca a sua voz e inicia a sua narrativa" (Ribeiro 200). Spatial references abound, as do personal ones. As Mata points out in her preface to $O$ Útero da Casa, the first two poems in the collection, "Mátria" and "A Casa," establish themselves as "signos equivalentes na busca de um sentido protector, de um lugar matricial em que assenta a busca da utopia e do sonho, aquele a nível colectivo, este a nível individual e afectivo-familiar" (12). The goal is to create a similarity between the island and the symbols of homeland and house. In this essay, I discuss the relationship between the poetic voice and the island, as well as the imagery conceived in the work of Conceição Lima, a poet born in Santana (São Tomé) during the colonial period, who explores the consequences of nationhood.

The border between the two types of island in Lima's work, the empirical island of reference and the "island of the imagination" is often blurred, as Helder Macedo argues, since the metaphorical integrates the factual (8). The island is impregnated with reality and specific references to its geography, such as place names, flora, fauna, Creole vocabulary, and cultural references to which historical events are related and reinterpreted emotively by the poetic voice. According to Mata, dedication and emotional episodes are particularly significant in the poet's first published anthology ("Apresentação" 14-15). Beyond the island, there are other places that return one to the notion of homeland; for example, in A Dolorosa Raiz de Micondó, Lima fuses the image of the island with that of the house. In this collection, the poetic voice deals with the impossibility of finding its roots because its ancestors from the African continent had left, "levando nos olhos o horror / e a luz da sua verdade e das suas palavras" (15). As the poetic voice's present has been built without the knowledge and memories of its ancestors, the house's location has yet to be established.

Mata argues that "o fluxo histórico ... parece ser a força motriz da produção de sentidos," highlighting the importance of the island's history for 
understanding Lima's work, even when that history is rendered in a dream-like fashion ("Apresentação" 12). In Lima's poetry, the history of the island starts in "Afroinsularidade," a "relato negro" in which the poetic voice describes the settlement of the islands in the fifteenth century (Falconi 186). Among the new inhabitants, there are two distinguishable categories: men and commodities:

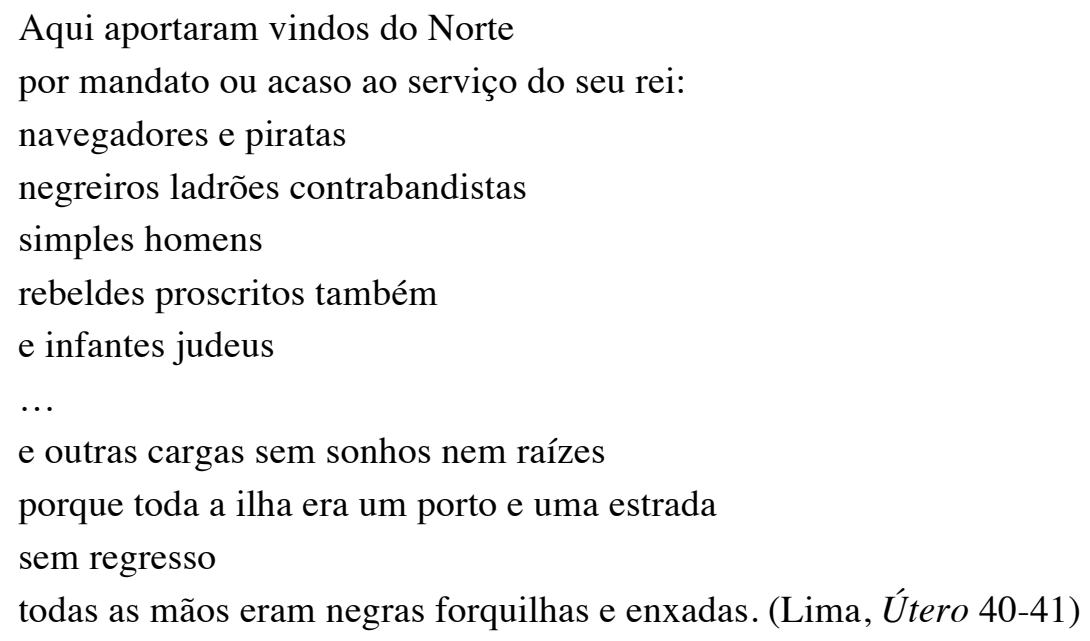

The cultural references in the poem to "creolization" and African/Portuguese cultural contact point to an identity of the colonized that floats between poles, an instance of an identity-in-flux that echoes Boaventura de Sousa Santos's description of Portuguese colonialism as "being neither an emancipatory nor an emancipated identity ... between Prospero and Caliban as if in search of Guimarães Rosa's third margin of the river" (36). As Ana Mafalda Leite has pointed out, this phenomenon is principally the result of Portuguese colonization strategies and the acculturation of the colonized (19). In Lima's poetry, a rebellious identity-in-flux comes across in references to syncretism, embodied in stark socio-cultural mixing - in churches and chapels alongside markers of the island's locality:

E nas ilhas ficaram

incisivas arrogantes estátuas nas esquinas

cento e tal igrejas e capelas

para mil quilómetros quadrados 
e o insurrecto sincretismo dos paços natalícios.

E ficou a cadência palaciana da ússua

o aroma do alho e do zêtê d'óchi

no tempi e na ubaga téla

e no calulu o louro misturado ao óleo de palma

e o perfume do alecrim

e do mlajincon nos quintais dos luchans. (Lima, O Útero 38)

Porosity in identity practices and diversity in the relationships between the colonizer and the colonized characterized Portuguese colonization (Santos 18). The colonizer left on the island "nomes sonoros aristocráticos" (Lima, Utero 39). In Lima's elegiac chant, the poetic voice builds a grim landscape of the island: "E nas roças ficaram pegadas vivas / como cicatrizes-cada cafeeiro respira agora um / escravo morto" (Lima, O Útero 40). Poems such as "Manifesto Inventado de um Serviçal" and "Kalua" (both contained in O Útero da Casa), and "Zálima Gabon" and "Raúl Kwata Vira Ngwaya Tira Ponha" (both found in A Dolorosa Raiz do Micondó) foreground peripheral groups in the history of the island, such as the contratados and their descendants (Mata, "Apresentação" 13). This grants them an importance in the narrative that is equivalent to the house: "Falo destes mortos como da casa, o pôr do sol, o curso d'água" (Lima, $A$ Dolorosa 22). ${ }^{1}$ This comparison is decisive for understanding the role that the homeland, metaphorically presented as the house, plays in Lima's work.

In "Manifesto Inventado de um Serviçal," the supplicant poetic voice addresses the islands, begging them to be a resting place: "Ilhas! Clamai-me vosso que na morte / não há desterro e eu morro ... / Sou filho da terra" (37). In the poem, it is possible to recognize the obvious wish of the poetic voice, a serviçal, to provide a homeland for a fringe group of the colonial society in which it is included. The vocatives throughout the poem call attention to, on one hand, the groups that contributed to marginalization- "irmãos," "ngwêtas," and "híbridos forros" - and, on the other, the islands - "chão inconquistado" and "ilhas" - as a powerful and free-willed entity that enables the allocation of the

\footnotetext{
${ }^{1}$ The contratados were workers (classified as "servants") from Angola, Mozambique, and Cabo Verde who went to São Tomé in the nineteenth and twentieth centuries during the cocoa and coffee cycles.
} 
land: "este barro é meu" (Lima, A Dolorosa 36; Mata, "A Poesia" 244). In this sense, writing enables one to conquer and claim the land (Mata, "A Poesia" 24445), going necessarily through the acceptance by the islands of the paternity - or perhaps more accurately the maternity - of this oppressed group.

In "1953," the Batepá Massacre is tackled and the poetic voice addresses Kwame Nkrumah, showing him the spleen of São Tomé city, the gutted result of one of the most atrocious events of the colonial period:

Olha como são introvertidos os muros da Avenida Marginal

Vê como são circunspectos os telhados dos chalés da Avenida Marginal

Olha como arquejam os tijolos dos chalés da Marginal

Sente a brisa quando roça os cabelos das palmeiras

nas artérias da cidade....

É o espírito dos que plantaram morrendo (Lima, Dolorosa 28)

The sepulchral landscape- "ossos visíveis, severos palpitam" (Lima, O Útero 23) - of a country haunted by the murdered and the fallen, receive a tribute in "Heróis": "Os mortos que morreram sem perguntas / regressam devagar de olhos abertos / indagando por suas asas crucificadas." In Lima's most recent poems, the poetic voice considers that "todos os guerreiros venceram" (Quando Florirem 34) and terrifying memories do not disturb the present anymore.

The independence of São Tomé e Príncipe is also referenced because "tudo aconteceu / nos mastros do poema" (Lima, O Útero 25) and broken dreams, the reality of the island's dysphoric present, appear in poems like "1975," "Herança" and "Sabemos Agora": "Sabemos agora que a Praça é minúscula / A extensão da nossa espera / Nunca coube em tais limites" (O Útero 28).

Lima does write poems proclaiming a time of hope on the island and prophesies:

Há-de nascer de novo o micondó

e não mais sonharão as crianças

com gatos pretos e águas turvas....

Reabitaremos a casa, nossa intacta morada. (A Dolorosa 67-68) 
The ambiguity of the house and the desire to build are related to the colonization of São Tomé e Príncipe and with a hybrid identity that characterizes the poetic voice, leading to a questioning of origins - "Quantos noms fundam transmutam minha fronte?" (Lima, O Útero 38). What becomes clear across Lima's work is a late awareness of the condition of being colonized: "Eu que tão tarde descobri em minha boca os caninos do antropófago...” (A Dolorosa 17).

Gaston Bachelard sees the house as a "body of images that give mankind proofs or illusions of stability" (90). As such, the house enables the poetic voice, lost in the "linearidade das fronteiras" (Lima, A Dolorosa 14), to start again in a place that offers protection. In "Mátria," a poem that introduces Lima's first book, O Útero da Casa, the poetic voice proclaims the return to the uterine space to undertake a journey to the most intimate retreat, feeling the body of the island: "Quero-me desperta / se ao útero da casa retorno / para tactear a diurna penumbra das paredes / na pele dos dedos reviver a maciez / dos dias subterrâneos / os momentos idos" (17). The criticism assumed in the agony that affects the poet, and noticeable in the homeland causes the island's rebirth from the deep sea, as one main, solid and vertical fortress: "Um degrau de basalto emerge do mar / e na dança das trepadeiras reabito / o teu corpo / templo mátrio / meu castelo melancólico / de tábuas rijas e de prumos" (O Útero 17-18).

This intimate island space appears as a poetic strategy that proclaims the desire for protection, comparable with what the house offers, that is so fertile in Lima's work. The project of the house begins to be forged, on the island, also as a place of enunciation that in the poem "A Casa" becomes something both concrete and based on past memories: "Aqui projectei a minha casa: / alta, perpétua, de pedra e claridade"; "Sobre os escombros da cidade morta / projectei a minha casa / recortada contra o mar" ( $O$ Útero 20 ). However, the poetic voice is aware of the unfinished address: "Sonho ainda o pilar-uma rectidão de torre, de altar" (20), and it does not give up: "E reinvento em cada rosto fio / a fio / as linhas inacabadas do projecto" (20).

In "A Ilha," the poetic voice projects a space "para decifrar do sonho / o começo e a consequência ... para rasgar sobre o pranto / o grito da imanência" (A Dolorosa 27), as if the poetic exercise were able to promote a reconciliation with the tragic past and, through some virtue, able to create a new world. In "Vila Maria Número 6," affection seems to be another way to neutralize the bitterness 
of the past, and it evokes happy and shared times on the island, a space-time where nature offers protection:

Gosto do quintal amplo, e de barro escuro, onde o verde do xapo-xapo é mais puro

e a polpa mais macia, mais algodão

Bananeiras alinhadas como soldados....

e os ramos das goiabeiras estendidos

como mãos....

Gosto da bananeira-flor, à entrada

erecta como um guardião

da simetria do leque

aberto em oferta

e da sombra que cai a pique

sobre a relva....

Há um cheiro vegetal, de pomar....

onde as horas se repartem como gomos iguais

e os encontros têm a conivente magia

dos rituais. (O Útero 52-53)

This house of affection, with a wide yard ("quintal amplo") and a guardian at the doorstep, marks the dialectic between inside and outside: "Enorme era a janela e de vidro / que a sala exigia um certo ar de praça / O quintal era plano, redondo / sem trancas nos caminhos" (O Útero 19). Despite having delineated boundaries, it is wide, and seeks to cover everything. Like Bachelard's house, it: "teach[es] how to breathe with the air that rests in the horizon and away from the walls and utopian prisons that anguish us" (235). Bachelard proposes an organization of the images of the house, in the framework of phenomenology of imagination, in which it is planned as a vertical and centralizing entity, defined as a space of double polarity (90). This definition is echoed in Lima, who declares "O basalto negro poroso viria da Mesquita / Do Riboque o barro vermelho da cor dos hibiscos para o telhado ... o quintal era plano, redondo" (O Útero 19). Bachelard compares the roof and the basement, opposing reasonableness and unreasonableness. In Lima's house, even though there is a basement, in the colors of indigenous materials, the same dichotomy exists, with the clarity of the roof 
opposing the dark being of the house found next to the floor (Bachelard 91). The birth place, in which "os dias eram longos e redondos e cercados" in the poem "São João da Vargem" ( A Dolorosa 57), is cast as a place of protection, a shelter for the poetic voice who, in childhood, did not question things: "Eu não meditava, eu não perguntava, eu não decifrava" ( $A$ Dolorosa 65 ). The poet escaped from the world and all affections: "No dia seguinte, ao fim da manhã, chegava a avó Nôvi ... / Trazia consigo a voz que apagava o ruído das coisas" (A Dolorosa 60). This exists in contrast with the moment of enunciation: "Vinha Dadá, gigante suave de pombas nos olhos / vinha por mim com mãos de algodão / que agora estão mortas e não me salvarão" ( $A$ Dolorosa 59), and the result is the illusion of a sense of belonging to the world:

Porque eu buscava a voz do sótão

quando fugia

e eu voava com as viuvinhas

quando corria e me escondia atrás dos troncos

Porque eu amava o sussurro dos canaviais

quando a verdade falava no grande quintal.

E eu dormia em paz, a casa era limpa no centro do anel. (Dolorosa 65-

66)

In childhood, when the yard was full of children's games, unconcerned with the stories that were told, "a casa crescia em pernas de pedra / com quartos enormes salas enormes / o enorme telhado de telhas vermelhas / e aquela varanda que não tinha fim," and with an attic which "era a caverna, era noturno e tinha cheiro de caixas fechadas" (A Dolorosa 64 ). The poetic voice pursued a mysterious place, similar to the one Bachelard outlines "that is naked, with pleasure, the strong bones of the beams. One can witness the solid geometry of the carpenter" (90). Both preceding houses offer protection, not only because of their architecture but also because of the presence of family and friends around, which avoided the "verdade que falava no grande quintal," which resulted from conversations related to events lived by society's marginalized groups (A Dolorosa 66).

In "Canto Obscuro às Raízes," the poetic voice imagines a journey to the African continent, specifically to Gabon, in an effort to find a lost house, as mentioned above. Through writing, the poet frees a "turvo canto e sua turva 
ascendência" (A Dolorosa 18), bemoaning the unfairness of the house assigned to her, because of an inability to locate her own origins given the ambivalent history of the islands:

Eu que em cada porto confundi o som da fonte submersa encontrei em ti, Libreville, o injusto património a que chamo casa: estas paredes de palha e sangue entrançadas, a fractura no quintal, este sol alheio à assimetria dos prumos a fome do pomar intumescida nas gargantas. (A Dolorosa 15)

This approach to the African continent demonstrates the relationship between the poetic voice and Africa, and a search for African roots, as Palmeira points out (9). This search is reinforced in Lima's $O$ País de Akendenguê, in which she chants not only of Africa in various references, but also of places held in great affection. The last poem in the collection, "Circum-Navegação," marks a notable return to the island: "Os barcos regressam / carregados de cidades e distância" (106).

The title of Lima's most recent volume, Quando Florirem Salambás no Tecto do Pico, suggests a happy island universe. In the poem that opens the book, the poetic voice names the house, so that "sovereign" words "elevate," as Lima puts it in O País de Akendenguê, "o reino que forjamos" (27). In Quando Florirem, the house is no longer a project: "Escrevo o teu nome na areia nua da praia / Escrevo a Sul, para nomear / a casa que me habita" (22). A rebirth is announced, with the rise of new dawn: "toco o ventre da manhã / a palpitação do fruto inadiável" (Quando Florirem 23). Appeasement is not yet complete, since the past remains ingrained on the island: "A ilha lembrava ainda a dolorosa travessia" (Quando Florirem 28), and "alguém em mim pergunta pelos antepassados" (Quando Florirem 25). The current political situation contaminates the state of mind of the poetic voice, postponing love:

Miriam foi raptada, não voltará da escolar

Com o seu lenço de seda e de confiança

A caneta carregada de promessa

E a pergunta nos invade e atravessa:

Ainda nos poderemos amar? 
Salvar-nos-emos dos abismos da surdez?

Aberta deixaremos a janela. (Quando Florirem 39)

Notwithstanding an "árdua herança," ghosts from the past are now missing, and a new and enchanted start is signaled: "ressuscitaram os campos, as tribos dançam / E as fronteiras em mim se desvanecem" (Quando Florirem 47). The individuality of this new beginning is then collectivized: "Recomeçamosartesãos da nossa redenção" (Quando Florirem 44). It is now the time for new discoveries, as pain is turned into love on an island where there is harmony, warm weather, and dazzling nature. The epigraph to O Útero da Casa, "Toda a ilha apela," and the poetic voice addresses "you" without a face who, as Palmeira points out (10), ranges between the land, the island, the sea, the rivers, and maybe the men, urging them all to "testemunhar este ingente nascimento" (Quando Florirem 46). The poet's injunction goes further, calling for a fellowship with the Other, as in "Quando Vieres," a poem from the section "O Coração da Ilha," in $O$ País de Akendenguê (99).

In Lima's work, the island is the place of houses and affections, of childhood and friends, but also a conquered landscape. The evoked places differ throughout the author's work, and they do not necessarily coincide with the San Tomean archipelago, although the island is the constant place of enunciation. The poetic voice narrates a painful journey in the search of identity and the poetic exercise promotes reconciliation with the tragic past creating a new world. The imaginary universe created by writing ensures protection-in the form of the island or corresponding to other intimate places full of affection, such as the house-and is also marked by empirical references.

A fulfilling return to the island, after an individual and imaginary journey that brings the poetic voice to the African continent, takes place in Quando Florirem Salambás no Tecto do Pico. The poetic voice claims the conquest of the space as a result of an arduous identity process, after emotively reinterpreting the historical events related to the colonization of São Tomé and Príncipe. The time of hope once prophesied is now possible to achieve.

The places haunted by the colonial past in the islands (such as the roça or the Avenida Marginal), a metonymy for the country or for the island(s), give rise to a harmonious geographic area and to the appeasement of harsh memories of the past, although the social and political situation is not excluded and still corrupts 
the state of mind of the poetic voice. The "crying obô" becomes "gracious forests," and this happy universe patent in natural elements leads to a new beginning, individual and collective. The desire of the poetic voice looks forward and shares with the Other the years to come on the island - an island built upon in Lima's verses that thus becomes more than land. It becomes the place one inhabits meaningfully, a home.

\section{Works Cited}

Bachelard, Gaston. "Poetics of Space (Extract)." Rethinking Architecture: A Reader in Cultural Theory. Ed. Neil Leach. London: Routledge, 1997. 8193. Print.

Falconi, Jessica. "A Língua de Conceição Lima: Um Novo País da Palavra." Literaturas Insulares: Leituras e Escritas de Cabo Verde e São Tomé e Príncipe. Ed. Margarida Calafate Ribeiro e Sílvio Renato Jorge. Lisbon: Afrontamento, 2011. 185-96. Print.

Ferreira, Manuel. Literaturas Africanas de Expressão Portuguesa. Vol. 1. Lisbon: Instituto de Cultura e Língua Portuguesa, 1986. Print.

Leite, Ana Mafalda. Literaturas Africanas e Formulações Pós-coloniais. Lisbon: Colibri, 2013. Print.

Lima, Conceição. O Útero da Casa. Lisbon: Caminho, 2004. Print.

-. A Dolorosa Raiz do Micondó. Lisbon: Caminho, 2006. Print.

-. O País de Akendenguê. Lisbon: Caminho, 2011. Print.

-. Quando Florirem Salambás no Tecto do Pico. São Tomé, 2015. Print.

Macedo, Hélder. "Prefácio.” O País de Akendenguê, by Conceição Lima. Lisbon: Caminho, 2011. 7-26. Print.

Mata, Inocência. "A Poesia de Conceição Lima: O Sentido da História e das Ruminações Afetivas." Veredas 7 (2006): 235-51. Print.

- . "Apresentação.” O Útero da Casa, by Conceição Lima. Lisbon: Caminho, 2004. 11-16. Print.

-. Polifonias Insulares: Cultura e Literatura de São Tomé e Princípe. Lisbon: Colibri, 2010.

Palmeira, Naduska. "As Ilhas sob a Pele da Linguagem: A Poética de Conceição Lima." Actas do Colóquio Internacional de São Tomé e Príncipe numa Perspectiva Interdisciplinar, Diacrónica e Sincrónica. Lisbon: Instituto 
Universitário de Lisboa/Centro de Estudos Africanos e Instituto de Investigação Científica Tropical. 2012. 383-91. Print.

Ribeiro, Margarida Calafate. "Património da Palavra: O Nome, a Casa, a Ilha." Literaturas Insulares: Leituras e Escritas de Cabo Verde e São Tomé e Príncipe. Ed. Margarida Calafate Ribeiro and Sílvio Renato Jorge. Lisbon: Afrontamento, 2011. 197-206. Print.

Santos, Boaventura de Sousa. "Entre Próspero e Caliban: Colonialismo, Póscolonialismo e Inter-identidade.” Luso-Brazilian Review 39.2 (2002): 9-43. Print.

Tenreiro, Francisco José. Ilha do Nome Santo. Coimbra: Coleção Novo Cancioneiro, 1942. Print. 